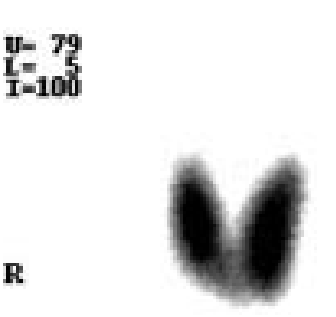

\title{
An interesting case of thirst and polyuria
}

\section{P K Moulik, C Nethaji, A A Khaleeli}

Answers on $p 251$. tenderness to deep palpation without any guarding or rigidity. Bowel sounds were present. The rest of the clinical examination was normal.

Investigations showed normal electrolytes, urea, creatinine, glucose 3.2 $\mathrm{mmol} / \mathrm{l}$, serum osmolality $297 \mathrm{mmol} / \mathrm{kg}$ water (reference range 288-298) and urine osmolality $178 \mathrm{mmol} / \mathrm{kg}$ water. Corrected serum calcium was raised at $3.01 \mathrm{mmol} / \mathrm{l}$ (reference range 2.15-2.55 $\mathrm{mmol} / \mathrm{l}$ ) with parathyroid hormone $(\mathrm{PTH})<0.08 \mathrm{pmol} / \mathrm{l}$ indicating nonparathyroid cause of hypercalcaemia. Insulin like growth factor 1 was normal at $17 \mathrm{nmol} / \mathrm{l}$ (reference range 15-64). She was rehydrated with intravenous isotonic saline and her dose of hydrocortisone temporarily increased but her hypercalcaemia persisted.

A water deprivation test was normal, with urine osmolality $1032 \mathrm{mmol} / \mathrm{kg}$ water and serum osmolality 287 $\mathrm{mmol} / \mathrm{kg}$ water after eight hours of water deprivation. Results of thyroid function tests were available at this stage showing free thyroxine $111 \mathrm{pmol} / \mathrm{l}$ with thyroid stimulating hormone $<0.03 \mathrm{mU} / \mathrm{l}$. Her thyroxine replacement was stopped and a ${ }^{99 \mathrm{~m}}$ technetium $\left({ }^{99 \mathrm{~m}} \mathrm{Tc}\right)$ pertechnate thyroid uptake scan was done after seven
Figure 1 Pertechnate thyroid uptake scan.

days (fig 1). Thyroid stimulating hormone receptor autoantibodies (TSHRAb) were positive at $75 \mathrm{U} / \mathrm{l}$ (reference range $<10 \mathrm{U} / \mathrm{l})$. Magnetic resonance imaging revealed an enlarged empty pituitary fossa with a thin rim of pituitary tissue in the periphery.

\section{QUESTIONS}

(1) What are the possible causes of thirst and polyuria in this woman?

(2) What are the possible causes of hypercalcaemia?

(3) What is the cause of her thyrotoxicosis?

(4) Is there an association between acromegaly and thyrotoxicosis?

Postgrad Med J 2002;78:248

Authors' affiliations

P K Moulik, C Nethaji, A A Khaleeli, Department of Medicine, Halton General Hospital, Runcorn, Cheshire, UK

Correspondence to: Dr P K Moulik, 39 Coniston House, University Hospital Aintree, Longmore Lane, Street, Liverpool L9 7AL, UK; p.moulik@virgin.net

Submitted 16 October 2001

Accepted 12 November 2001

\section{A proliferating pimple}

\section{S Puppala, V P Muralikrishnan, D M Wayte, L R Jenkinson}

biopsy of the lesion was performed and the histology was as shown in the fig $1 \mathrm{~B}$.

Answers on $p 251$.

A 63 year old man was referred by the general practitioner with skin lesion on the right buttock which he had for three months. The lesion started as a small "pimple" and gradually increased in size. It was associated with occasional minor bleeding and pain when touched.
There were no other systemic symptoms and no associated past medical history. Physical examination revealed a $5 \mathrm{~cm}$ firm erythematous skin nodule with involvement of the subcutaneous tissue as shown in the fig 1A. There was an indurated erythematous "halo" around its base. A

\section{QUESTIONS}

(1) What is the differential diagnosis on clinical examination?

(2) What does the histology reveal and what histological techniques are used to establish the diagnosis?

(3) Discuss the clinical features and management of this lesion.

Postgrad Med J 2002;78:248 


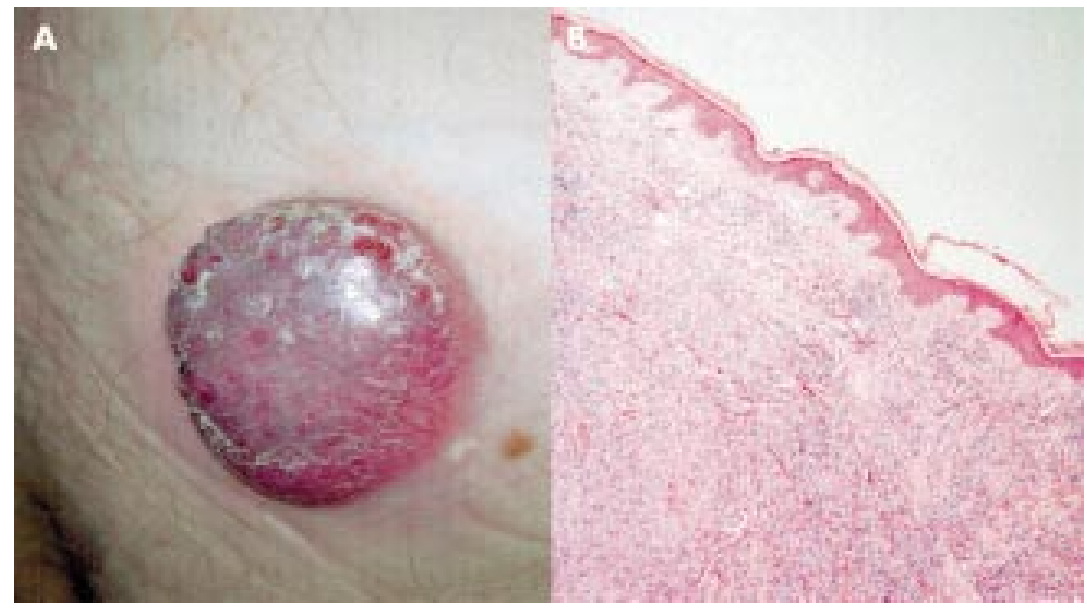

Figure 1 (A) Erythematous skin nodule and (B) histology of lesion.

Rash

\section{An episodic eruption}

\section{P Bentley, A Keat}

\section{Answers on p 252.}

$\mathrm{A}$

72 year old woman presented with a fleeting rash, lasting several days at a time, on both thighs and lower trunk, over a four month period (fig 1). The eruption was non-pruritic and nonpalpable, and occurred on different parts of the legs at different times. She had a 30 year history of seropositive, erosive rheumatoid arthritis and a five year history of secondary Sjogren's syndrome. The patient also had two sinuses on the sole of her right foot, which had been present for a year, and which were being treated conservatively with cleansing and dressing. There were no other new symptoms on admission. Her medication had not changed in over a year, and consisted of methotrexate $15 \mathrm{mg} /$ week (plus folic acid), prednisolone $15 \mathrm{mg} /$ day, diclofenac, thioridazine, and doxepin.

She had a mild normocytic anaemia (haemoglobin concentration $117 \mathrm{~g} / \mathrm{l}$ ) with a raised ferritin level $(531 \mu \mathrm{g} / \mathrm{l})$,

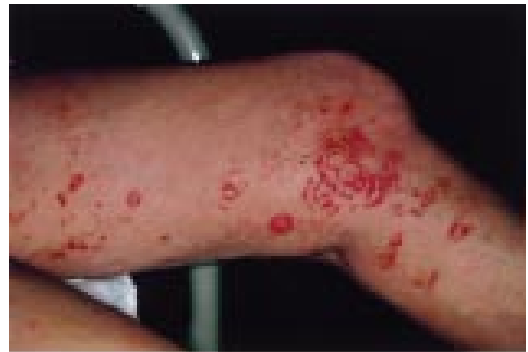

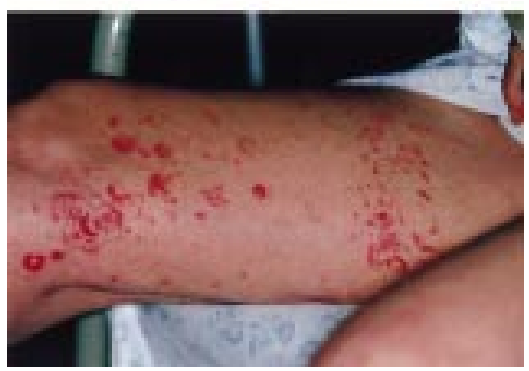

Figure 1 Rash on medial aspect of both legs (reproduced with patient's permission).

while leucocyte and platelet counts were normal. Renal and liver function blood tests, as well as plasma calcium and phosphate concentrations were all within the normal range. The erythrocyte sedimentation rate (Westergren) was $42 \mathrm{~mm}$ in the first hour, and C-reactive protein level was $62 \mathrm{mg} / \mathrm{l}$. Rheumatoid factor titre was 320; tests for antinuclear antibodies, antibodies for extractable nuclear antigen, and cryoglobulins were negative.

\section{QUESTIONS}

(1) What is the name given to this rash, and how is the appearance described?

(2) What underlying diseases does it suggest?

Postgrad Med J 2002;78:249

Authors' affiliations

P Bentley, A Keat, Department of

Rheumatology, Northwick Park Hospital,

Harrow, Middlesex, UK

Correspondence to: Dr P Bentley, Wellcome Department of Imaging Neuroscience, Institute of Neurology, 12 Queen Square, London WCIN 3BG, UK

Submitted 10 January 2001

Accepted 3 July 2001 
Jaundice and fever

\section{A 15 year old girl with fever, jaundice, haemolysis, and sudden clinical deterioration}

\section{Pirisi, B Branca, C Avellini, A Solinas}

A 15 year old girl presented to an internal medicine ward with a two day history of jaundice and intermittent, high grade fever. Low grade fever and constitutional symptoms had been present for three weeks, during which the only medication taken was ibuprofen. Her mother recalled having found rat excrement in her knapsack, after the girl had returned from a rural resort, a few days before the onset of her illness. All family members had eaten seafood on a single occasion, two weeks before admission. She was not sexually active, had never been transfused, had no known exposure to hepatotoxic chemicals, and did not drink alcohol or use recreational drugs. There was no family history of liver disease or of recent travel to foreign countries. On physical examination, she was alert and cooperative. There was hepatomegaly and diffuse abdominal tenderness; ascites and stigmata of chronic liver disease were absent.

Laboratory data are shown in table 1 . There were no schistocytes on the blood smear, nor were corneal opacities found at slit lamp examination. Abdominal ultrasound and duplex Doppler sonography confirmed the presence of marked liver enlargement (longitudinal diameter $20 \mathrm{~cm}$ ); spleen longitudinal diameter was $14 \mathrm{~cm}$. Bile ducts were not dilated, the hepatic artery, portal vein
Table 1 Haematological and blood chemistry values

\begin{tabular}{|c|c|c|}
\hline Variable* & Value & Normal range \\
\hline White blood cells $\left(\times 10^{9} / \mathrm{l}\right)$ & 26.2 & $4.5-9.8$ \\
\hline Red blood cells $\left(\times 10^{12} / \mathrm{I}\right)$ & 1.91 & $4.2-5.6$ \\
\hline Haemoglobin (g/l) & 65 & $120-160$ \\
\hline Packed cell volume & 0.19 & $0.37-0.47$ \\
\hline Platelets $\left(\times 10^{9} / 1\right)$ & 364 & $140-400$ \\
\hline MCV (fI) & 99 & $82-98$ \\
\hline Absolute reticulocyte count $\left(\times 10^{9} / 1\right)$ & 191 & \\
\hline Prothrombin time (sec) & 26.3 & \\
\hline INR & 2.64 & \\
\hline Bilirubin ( $\mu \mathrm{mol} / \mathrm{l})$ & 347 & $3-17$ \\
\hline Alkaline phosphatase (U/I) & 8 & $32-104$ \\
\hline Alanine aminotransferase (U/I) & 20 & $10-36$ \\
\hline Lactate dehydrogenase (U/I) & 817 & $211-423$ \\
\hline Haptoglobin & Undetectable & \\
\hline Coombs test (direct and indirect) & Negative & \\
\hline Glucose-6-phosphate dehydrogenase & Normal & \\
\hline Pyruvate kinase & Normal & \\
\hline Autoantibodies (SMA, ANA, and MIT) & Negative & \\
\hline Serology for hepatitis viruses A, B, and C & Negative & \\
\hline Ceruloplasmin (mg/dl) & 20.8 & $20-60$ \\
\hline
\end{tabular}

${ }^{*} \mathrm{MCV}$, mean corpuscular volume; INR, international normalised ratio; SMA, antismooth muscle antibodies; ANA, antinuclear antibodies; MIT, antimitochondrial antibodies.
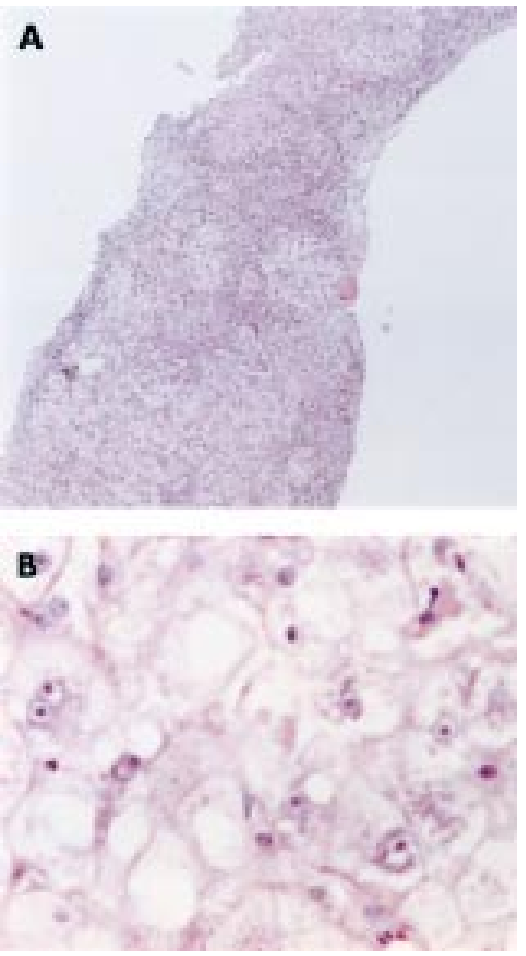

Figure 1 Liver biopsy specimen: $(A)$ haematoxylin and eosin $\times 100$ and $(B)$ haematoxylin and eosin $\times 400$.

and hepatic veins were patent, and there was no free peritoneal fluid.

In the next six hours confusion, anuria, and respiratory distress ensued. The patient was transferred to an intensive care unit and a liver biopsy was performed (fig l).

\section{QUESTIONS}

(1) What does the liver biopsy show?

(2) What is the most likely diagnosis?

\section{Authors' affiliations}

M Pirisi, B Branca, C Avellini, Liver Unit, University of Udine, Italy

A Solinas, Chair of Gastroenteology, University of Sassari, Italy

Correspondence to: Professor Mario Pirisi, Università del Piemonte Orientale "Amedeo Avogadro", Dipartimento di Scienze Mediche, Via Solaroli 17, 28100 Novara (NO), Italy; mario.pirisi@med.unipmn.it

Submitted 2 July 2001

Accepted 27 November 2001 